\title{
Impact of Cane Growth, Yield and Water Productivity under Sustainable Sugarcane Initiative (SSI) Technology
}

\author{
K. Thirukumaran* and K. Kavitha \\ ICAR-Krishi Vigyan Kendra, Tamil Nadu Agricultural University, \\ Thirupathisaram, Kanyakumari District, India \\ *Corresponding author
}

Keywords

SSI method,

Drip irrigation,

Sugarcane yield,

Water productivity

Article Info

Accepted:

18 March 2020

Available Online:

10 April 2020

\section{A B S T R A C T}

Sustainable Sugarcane Initiative (SSI) is one of the advanced methods of sugarcane cultivation technique which involves the use of less seed setts, water, land, labour and optimum utilization of fertilizers to achieve maximum potential yield. The SSI is an alternative to conventional method of sugarcane cultivation. The field demonstrations were conducted in farmer's field at five different locations to study the effect of sustainable sugarcane initiative and conventional sugarcane cultivation under drip irrigation system during 2017 - 2018. Sugarcane grown under SSI method produced taller plants, more number of tillers, milleable cane and lengthier internodes than the conventional method of planting. The SSI method under drip irrigation system produced higher average cane yield of $118.8 \mathrm{t}$ $\mathrm{ha}^{-1}$ over conventional planting under drip irrigation which was 30 per cent higher than the conventional planting. SSI planting recorded higher water productivity $\left(8.14 \mathrm{~kg} \mathrm{~m}^{-3}\right)$ than the conventional method of cultivation $\left(6.26 \mathrm{~kg} \mathrm{~m}^{-3}\right)$. Therefore, SSI technology could be proved as an innovative, improved technology and it could be recommended to the sugarcane growing farmers for increasing productivity.

\section{Introduction}

Sugarcane is one of the important cash crops grown in India and plays a vital role in both agricultural and industrial economy of our country. There are 35 million farmers growing sugarcane and another 50 million depend on employment generated by the 571 sugar factories and other related industries using sugar. In Uttar Pradesh, Maharashtra and Tamil Nadu, sugarcane crop plays a major role in the state economy. During the last 10 years, sugarcane production in India has been fluctuating from 233 to 355 million tonnes. The national productivity also at the farm level is as low as $40 \mathrm{t} / \mathrm{ha}$. With such low yields and fluctuations in production, India is the second country having largest area under 
sugarcane cultivation in the world next to Brazil, the industry is in for big trouble.

The problem of water scarcity is going to further deteriorate due to variability of rainfall influenced by climate change. So, unless sugarcane farmers are provided with options of high yields with much less water, India will find it difficult to meet its growing demand for sugar. Under such situation development of new technology of Sustainable Sugarcane Initiative (SSI) will be the viable option to achieve maximum productivity. The present demonstrations were conducted in the farmer's field to study the effect of SSI and conventional sugarcane cultivation under drip irrigation system.

\section{Materials and Methods}

The field demonstrations were conducted at five different locations of farmers' field in four blocks of Thiruvannamalai district during 2017 - 2018 to study the effect of sustainable sugarcane initiative and conventional sugarcane cultivation under drip irrigation system. These demonstrations mainly focused on the yield maximization of sugarcane under SSI compared with conventional method of planting.

The field was ploughed for 2 to 4 times at the depth of 50-60 cm with tractor drawn disc plough. The secondary tillage operation of harrowing was done at a shallow depth of 12$15 \mathrm{~cm}$ to crush the clods by disc harrow to pulverizes, smoothens and compact the soil to conserve the moisture. A well decomposed FYM at 12.5 ton $\mathrm{ha}^{-1}$ was applied before the last ploughing. The sugarcane variety $\mathrm{CO}$ 86032was used for all the demonstrations. The seedlings were raised in the protray for 25 - 30 days. The single budded chips were collected from 8 month old healthy plant using bud chipper. Then buds were treated with either chemical or biological method.
The treated buds were collected in the gunny bag and placed in a dark room for 4- 5 days for incubation. After completion of incubation period, healthy sprouted buds were selected and placed on the $1 / 4$ th filled coir pith portray and covered the bud chips in trays completely with coir pith. Watering was done based on the moisture content of coir pith. The main field was irrigated through drip irrigation system immediately after transplanting. After 30 days of transplanting, mother shoot was removed. For conventional planting, two budded setts were planted on both sides of trenches with centre gap of $30 \mathrm{~cm}$ at $90 \mathrm{~cm}$ apart and gap filling was done on 20 Days After Planting (DAP).

Source of irrigation was an open well. Irrigation water was pumped through motor and it was conveyed to field using PVC pipes of $90 \mathrm{~mm}$ after filtering through disk filter. The main line delivered the water to the field through sub mains of $63 \mathrm{~mm}$ diameter pipes and sub main, $16 \mathrm{~mm}$ size laterals were fixed at a spacing of $150 \mathrm{~cm}$. The operating pressure was maintained at $1.5 \mathrm{~kg} \mathrm{~cm}^{-2}$. The drip irrigation system was well maintained by flushing and cleaning the filters. Irrigation was given once in two days. The recommended fertilizer dose of 275:63:115NPK kg ha ${ }^{-1}$ (Fig. 1) was given as per the fertigation schedule starting from 15 to 210 DAP.

\section{Results and Discussion}

The morphological characters such as plant height and tiller number (Table 1), SSI planting method registered taller plants (320 $\mathrm{cm}$ ) with more number of tillers (21 tillers plant $^{-1}$ ) than conventional method. Plants were taller in SSI method, because of wide spacing offered less competition between tillers for sunlight, nutrient, moisture and less population. The results are in accordance with the findings of Nagendran and Palanisamy 
(1997). The production of more tillers might be due to manual removal of mother shoot at 30DAP. Moreover, adopting wider spacing also induce more tillers due to better aeration. This finding was corroborated with WonChong and Martin (1981). Parathatharthy (1962) reported germination and subsequent tillering are important factors for deciding the final population of millable cane at harvest.

The cane yield components affecting the final yield of sugarcane are the number of millable cane, cane weight and cane diameter, cane height and number of internodes per cane (Singh and Singh, 1954). In the present study with respect to the internode characters, number of internodes and their length and width were increased under SSI system, which was 28 nodes, $13.6 \mathrm{~cm}$ and $2.9 \mathrm{~cm}$, respectively than conventional planting (24 nodes, $10.6 \mathrm{~cm}$ and $2.4 \mathrm{~cm}$, respectively). Increased number of internodes and their length and width were due to wider spacing which harnesses more solar radiation. The results were supported by Nagendran and Palanisamy (1997).

Srivastava et al., (1992) reported that cane growth was mainly governed by initial growth phases i.e., germination which affect the production of tillers and finally number of millable cane one of the main yield contributing characters. Tillering capacity at 60 days showed positive association with number of millable cane and cane yield indicated the importance of tillering to dictate the final cane yield. Thangavellu (2004) indicated that tillering phase was the largely determine the productivity of sugarcane crop. This was reflected in the present study also, higher number of millable canes of 17 number plant $^{-1}$ was registered in the SSI planting method and single cane weight of $2.27 \mathrm{~kg}$ cane $^{-1}$ which was 26 percent increased weight over conventional planting method $(1.80 \mathrm{~kg}$ cane $\left.^{-1}\right)$. Increased millable cane number and single cane weight leads increased cane yield of $119.8 \mathrm{t} \mathrm{ha}^{-1}$ registered in SSI planting than normal planting method $\left(92.5 \mathrm{t} \mathrm{ha}^{-1}\right)$. Among five locations, sokampalayam village recorded higher cane yield of $131.4 \mathrm{t} \mathrm{ha}^{-1}$ under SSI-drip system than conventional drip system. This was attributed by the enhancement of yield is due to localized placement of manures and sufficient utilization of light and air as well as nutrients. The sufficient light and air improves plant structure which reduces disease incidence and insect infestation. Sufficient space between rows helps in operations like spraying, dusting and propping. Besides this, the root zone is deeper thus remained always moist.

With respect to quality characters, brix reading, poll and purity percentage also higher(18.3, 15.2 and 84.1 percentages respectively) under SSI drip system than conventional drip system (17.3, 13.8 and 79.7 $\%)$. Kamat and Singh (2002) reported that association of tillers count to the biochemical traits namely, juice purity, juice brix and juice pol percentage was non-significant indicated these characters are independent, this might be due to the varietal difference in maturity date. As per Sastri and Venkatachari (1960), quality of cane juice depends upon many factors like variety and age of the crop.

Regarding water consumption and productivity, the same amount of irrigation water of $1460 \mathrm{~mm}$ was applied for both planting system, but higher water productivity of $8.24 \mathrm{~kg} \mathrm{~m}^{-3}$ was registered in SSI method then conventional planting $\left(6.36 \mathrm{~kg} \mathrm{~m}^{-3}\right)$. The WUE values were in the 6 to $12 \mathrm{~kg} \mathrm{~m}^{-3}$ range (Thompson, 1976; Kingston, 1994; InmanBamber et al., 1999), but higher values of 22 to $48 \mathrm{~kg} \mathrm{~m}^{-3}$ are also reported (Robertson and Muchow, 1994; Inman-Bamber et al., 1999) depending on the irrigation scheduling strategy, seasonal rainfall and stage of development. 


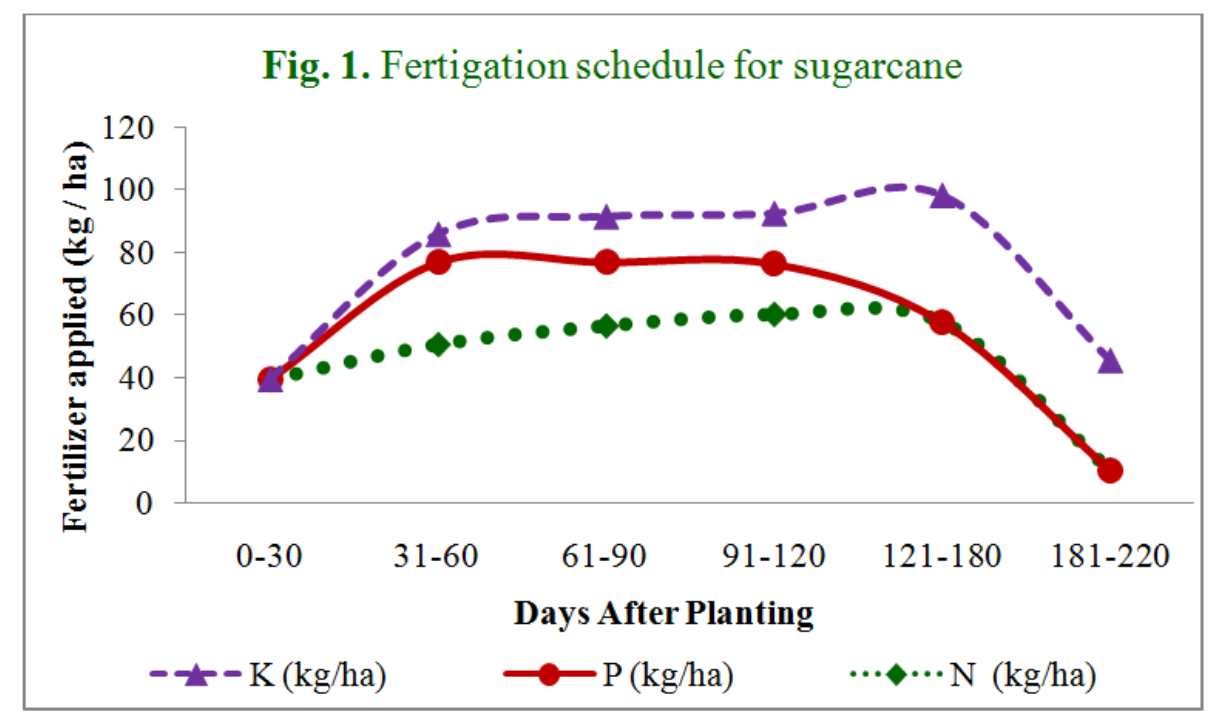

Table.1 Effect SSI on morphological characters under drip system

\begin{tabular}{|c|c|c|c|c|c|c|c|c|}
\hline \multirow[t]{2}{*}{ Parameters } & \multicolumn{2}{|c|}{ Thandrampattu } & \multicolumn{2}{|c|}{ Polur } & \multicolumn{2}{|c|}{ Chengam } & \multicolumn{2}{|c|}{ Keelpennathur } \\
\hline & $\begin{array}{c}\text { SSI } \\
\text { planting }\end{array}$ & $\begin{array}{l}\text { Normal } \\
\text { planting }\end{array}$ & $\begin{array}{c}\text { SSI } \\
\text { planting }\end{array}$ & $\begin{array}{l}\text { Normal } \\
\text { planting }\end{array}$ & $\begin{array}{c}\text { SSI } \\
\text { planting }\end{array}$ & $\begin{array}{l}\text { Normal } \\
\text { planting }\end{array}$ & $\begin{array}{c}\text { SSI } \\
\text { planting }\end{array}$ & $\begin{array}{l}\text { Normal } \\
\text { planting }\end{array}$ \\
\hline Plant height $(\mathrm{cm})$ & 316 & 295 & 330 & 295 & 328 & 289 & 320 & 274 \\
\hline $\begin{array}{l}\text { Number of tillers } \\
\text { plant }^{-1}\end{array}$ & 21 & 9 & 20 & 11 & 19 & 11 & 23 & 17 \\
\hline $\begin{array}{l}\text { Number of } \\
\text { internodes }\end{array}$ & 26 & 20 & 31 & 24 & 28 & 24 & 28 & 24 \\
\hline $\begin{array}{l}\text { Internode length } \\
(\mathrm{cm})\end{array}$ & 12.8 & 10.7 & 14.9 & 11.2 & 13.9 & 10 & 12.8 & 10.1 \\
\hline $\begin{array}{l}\text { Internode Girth } \\
\text { (cm) }\end{array}$ & 2.4 & 2.1 & 2.2 & 2.0 & 3.1 & 2.6 & 3.5 & 2.5 \\
\hline $\begin{array}{l}\text { Milleable cane } \\
\text { number plant }^{-1}\end{array}$ & 17 & 11 & 18 & 8 & 16 & 8 & 18 & 10 \\
\hline $\begin{array}{l}\text { Single cane } \\
\text { weight (kg) }\end{array}$ & 2.43 & 1.75 & 2.22 & 1.56 & 2.23 & 1.78 & 2.22 & 2.13 \\
\hline $\begin{array}{l}\text { Cane Yield } \\
\left(\text { tonnes ha }^{-1}\right)\end{array}$ & 108.9 & 86.2 & 131.4 & 98.9 & 112.4 & 89.5 & 118.2 & 90.3 \\
\hline Brix content (\%) & 18.3 & 17.3 & 18.6 & 17.4 & 18.2 & 17.1 & 18.4 & 17.0 \\
\hline Poll (\%) & 15.9 & 13.7 & 15.4 & 13.8 & 15.1 & 13.9 & 15.0 & 13.6 \\
\hline Purity (\%) & 86.7 & 79.3 & 82.7 & 79.1 & 82.2 & 79.8 & 85.5 & 80.5 \\
\hline $\begin{array}{l}\text { Water } \\
\text { consumption } \\
(\mathrm{mm})\end{array}$ & 1562 & 1562 & 1438 & 1438 & 1300 & 1300 & 1487 & 1487 \\
\hline $\begin{array}{l}\text { Water } \\
\text { productivity } \\
\left(\mathrm{kg} \mathrm{m}^{-3}\right)\end{array}$ & 6.97 & 5.52 & 9.14 & 6.88 & 8.65 & 6.88 & 7.95 & 6.07 \\
\hline
\end{tabular}


From the results, it could be concluded that among the five different locations, SSI planting recorded higher productivity both in terms of yield and water than conventional planting. Hence, SSI technology proved as an innovative, improved technology and it could be recommended to the sugarcane growing farmers for increasing productivity.

\section{References}

Inman-Bamber, N.G., Robertson, M.J., Muchow, R.C., Wood, A.W., Pace, R. and Spillman, A.F.M. (1999). Boosting yields with limited water. Proc. Aust. Soc. Sugar Cane Technol, 21, 203-211.

Kamat, D.N. and Singh, J. R. P. (2002). Correlation studies in sugarcane under rainfed condition. Annals of Biol., 18(2), 117-119.

Kingston, G. 1994. Bench marking yield of sugarcane from estimates of water use. Proc. Aust. Soc. Sugar Cane Technol. 16: 201-209.

Nagendran, K. and Palanisamy, R. (1997). "Spaced row cane planting system for better yield and returns". $30^{\text {th }}$ meeting of sugarcane research and development workers of Tamil Nadu. Appakudal (TN), $32-38$.

Parathasarthy, S.V. (1962). "Anew method of planting sugarcane". The Madras
Agricultural Journal, 48, 203.

Robertson, M.J. and Muchow, R.C. (1994)."Future research challenges for efficient crop water use in sugarcane production". Proc. Aust. Soc. Sugar Cane Technol, 16, 193-200.

Sastri, S.A. and Venkatachari. (1960). "Juice quality of sugarcane A review". Indian J. Sugarcane Res., 5, 15-27.

Singh, M. and Singh, H. (1954). "Certain Correlation Studies in sugarcane". In: Proceeding of Biannual Conference Sugarcane Research Development. Warkers, 2: 70-78.

Srivastava, A., Gocsh, A. K. and Agnithorti, V.P. (1992). "Sugarcane Ratoon", Oxford and IBH Publishing Co. Pvt. Ltd., India.

Thangavellu (2004). "Study of tillers in sugarcane genetic stocks and cane and sugar yield". Indian Sugar Journal, 601-602.

Thompson, G.D. (1976)."Water use by sugarcane".SA Sugar J, 60, 627635.Wong-Chong, J. and Martin, F.A. (1981). Tillering in Sugarcane as affected by genotype and plant growth regulator. Sug. Azu., 76(11): 56-57.

Wong-Chong, J. and Martin, F.A. (1981). Tillering in Sugarcane as affected by genotype and plant growth regulator. Sug. Azu., 76(11): 56-57.

\section{How to cite this article:}

Thirukumaran, K and Kavitha, K. 2020. Impact of Cane Growth, Yield and Water Productivity under Sustainable Sugarcane Initiative (SSI) Technology. Int.J.Curr.Microbiol.App.Sci. 9(04): 2306-2310. doi: https://doi.org/10.20546/ijcmas.2020.904.276 